\title{
The AzAs (Antizionist Antisemitism) Scale: Measuring Antisemitism as Expressed in Relation to Israel and Its Supporters ${ }^{1}$
}

\author{
Daniel Allington and David Hirsh ${ }^{2}$
}

\begin{abstract}
This paper reports on the development and testing of the AzAs (Antizionist Antisemitism) scale: a six-item questionnaire instrument for measuring antisemitic attitudes as articulated in the language of hostility to Israel and its supporters. It is important to be able to recognize and measure this kind of antisemitism because it is often embedded within ostensibly democratic discourse. The identification of this antisemitism is frequently contested even by those who are in broad agreement on the recognition of older forms of antisemitism. The scale contains a balance of protrait and contrait items, and achieved a satisfactory level of internal consistency when piloted on a sample of US-based respondents recruited through the Mechanical Turk crowdsourcing market $(N=122)$. There appears to be no relationship between scores on the scale and the subjective political position of respondents (as measured on a left-right self-report scale). We suggest that the AzAs scale will be of general use in measuring antizionist antisemitism because (a) it collects several familiar and demonstrably antisemitic ideas expressed in relation to Israel and its supporters and (b) it exhibits good psychometric properties.
\end{abstract}

Keywords: Antisemitism, Antizionism, Attitudes, Israel, Questionnaire instrument

\section{ANTIZIONISM AND ANTISEMITISM}

So many experimental and survey-based studies have found a correlation between negative attitudes towards Jews and negative attitudes towards Israel that this may be considered one of the most solidly established facts of political psychology. ${ }^{3}$ That is unsurprising: multiple historical and qualitative studies have argued for the existence of a manifestation of antisemitism which is expressed in relation to discourse about Israel and which may not necessarily be expressed against Jews qua Jews. ${ }^{4}$ If that argument is accepted, then it seems possible that the empirical correlation between agreement with certain kinds of statements about Jews and agreement with similar attitudes about Israel may reflect a relationship not of causation but of identity. In other words, it is perhaps not that certain kinds of attitudes to Israel drive certain kinds of attitudes to Jews, or vice versa, but that there is only a single social and psychological construct underlying both. This argument could be taken to suggest that much of the imperfection of the empirical correlation between agreement with classically antisemitic statements referring to Jews and agreement with the same statements once modified to refer instead to the Jewish state may be explained by the effects of social desirability bias with regard to the expression of prejudice against ethnic or religious minority groups. 
"Denial of racism" is, it has been observed, "a key feature of modern racism." 5

For example, several of the items within the questionnaire instrument used for the 2017 Jewish Policy Research study of attitudes to Jews and Israel express clearly antisemitic attitudes with reference to "Israel" rather than "Jews." To take perhaps the clearest example, the statement "Israel exploits Holocaust victimhood for its own purposes" (agreed with by about thirteen percent of the British population), which is part of the group of statements which that study uses to measure what it refers to as "anti-Israel attitudes," is almost identical to the statement "Jews exploit Holocaust victimhood for their own purposes" (agreed with by about ten percent of the British population), which is part of the group of statements which the same study uses to measure what it refers to as "antisemitic attitudes." While it is obvious that these two groups of statements had to be held conceptually separate in order to answer that study's central research question, which concerned the statistical association between agreement with one group and agreement with the other, it would be difficult to argue that the second of the two statements quoted here is any less antisemitic than the first. After all, they both express the same idea-albeit that one expresses it in relation to Jews, and the other, in relation to the Jewish state. Moreover, it is as implausible to suppose that Israel-haters will have taken "Israel" to refer to Israel's non-Jewish inhabitants as it is to suppose that Jew-haters will have understood Jews' "own purposes" to be unrelated to Israel. Indeed, the usual antisemitic claim is that Jews exploit the Holocaust to legitimate Israel's existence as a Jewish state. ${ }^{7}$ This may explain why the same study found "Jews exploit Holocaust victimhood for their own purposes" to be the most popular antiJewish statement among people with strong anti-Israeli attitudes, receiving agreement from a staggering forty-nine percent of the latter. ${ }^{8}$

This is not, of course, to criticize the Jewish Policy Research study and those similar studies that preceded it, which could only have been conducted on the methodological basis of an artificial distinction between statements about Israel and statements about Jews. Rather, it is to argue that the best response to those studies is to build on their repeated finding of correlation by abandoning the fiction of an essential difference between antisemitism and that form of antizionism promoted not only by the notionally leftwing BDS (Boycott, Divestment, and Sanctions) movement but also by right-wing extremists such as the white supremacist, David Duke.

This is not to say that contemporary antiIsrael discourse is no more than a "politically correct" veneer on an unchanging anti-Jewish prejudice. After all, the international delegitimization campaign against Israel was not spontaneous in emergence, but the work of a decentralized network of individuals and groups that exhibit considerable diversity with regard both to ideology and to objectives. Nonetheless, it is clear that much of the discourse generated by that campaign rotates around a collection of tropes that should be instantly recognizable from earlier expressions of Jew-hate. ${ }^{10}$ Moreover, where negative attitudes to Israel are "manifested in . . . hostility and violence against Jews and Jewish communities abroad," as is often the case, ${ }^{11}$ then we can only be witnessing antisemitism in practice, even if the perpetrators would characterize their speech and actions otherwise: for example, as "politically motivated" hostility and violence towards supporters of Israel who are, they might argue, only coincidentally Jewish. This line of argument has indeed been maintained even where violence is targeted not at an Israeli or pro-Israeli target but at a Jewish place of worship in a European country. ${ }^{12}$ Under such circumstances, there is little sense in asking whether Jews are being conceived as a proxy for Israel or whether Israel is being conceived as a proxy for Jews. Classically antisemitic discourse is used to delegitimize Israel, and discourse on Israel is used to legitimize what would otherwise be easily recognizable as antisemitic behavior. 
Both change and continuity are therefore involved. One of the boldest theories of continuity has been put forward by Thorsten Fuchshuber. He argues that both "antisemitism" in the sense in which the word is most commonly understood-that is, as a term covering the racialized Jew-hate which emerged in nineteenth-century Germany and the related exterminationist Jew-hate associated with the Holocaust-and twenty-first-century "antiZionism"-that is, the seemingly democratic Jew-hate which today uses the language of human rights to condemn the most visible and important Jewish collectivity (i.e., the state of Israel)—are simply two successive strategies. Each is adapted to a different social reality, for the purpose of (a) inflicting the maximum possible harm to Jews and (b) rationalizing such harm in a manner acceptable to wider society. ${ }^{13}$ As Fuchshuber writes, "antizionism is a new form of Judeophobia only in the sense that what stands between the Jew haters and their enemy (the Jew) has changed," such that "Israel is merely the new obstacle that stands between Judeophobes and the fulfilment of their unsubstantiated hatred against the Jews." ${ }^{14}$

Fuchshuber's arguments could be taken to suggest a level of essentialism and intentionality that might be regarded as controversial. But one can make a similar point whilst avoiding such implications: for example, David Seymour argues that antisemitism and antizionism should be understood as analogous ideologies (in Arendt's sense). ${ }^{15}$ Either way, it is insufficient simply to observe that negative attitudes towards Israel tend to co-occur with negative attitudes towards Jews qua Jews: if the division of these attitudes into distinct and nonoverlapping sets is arbitrary and unstable, then there is no reason to assume that attitudes from different sets would not co-occur.

Although we note Fuchshuber's use of the term "Judeophobia" to represent that which is constant between religious anti-Judaism, racialized and exterminationist antisemitism, and contemporary antizionism, we retain the term "antisemitism" as the most widely accepted term for all these forms of Jew-hate, using the term "antizionist antisemitism" to refer to the form of anti-Jewish ideology which has been articulated in relation to the state of Israel. To measure the prevalence of that ideology in a consistent and replicable manner, a standard instrument will be required. However, existing questionnaire instruments for the measurement of antisemitism are founded on an understanding of antisemitism which regards as paradigmatic only those anti-Jewish attitudes which predate the foundation of the state of Israel. That is why the experimental and survey-based studies referred to in the first paragraph of this section impose an a priori distinction between Israel and Jews when such a distinction clearly has no stable psychological reality in the minds of those who hate either-as the findings of those studies must be recognized to suggest.

In constructing and piloting the AzAs (antizionist antisemitism) scale, we have attempted to move on from the above by constructing and piloting a set of statements designed to elicit antisemitic attitudes (or their negation) with reference to Israel and its supporters.

\section{DEVELOPMENT OF THE AZAS SCALE}

Questionnaire items were initially developed through brainstorming between the two authors, each of whom has substantial experience of qualitative research on contemporary antisemitism. Following discussion with other antisemitism experts and practitioners, these were incorporated in an online questionnaire hosted on Google Forms.

During the construction of the online questionnaire, it was recognized that the overwhelmingly antisemitic nature of most of the statements could make completing it into a distressing experience for Jewish respondents. For that reason, a number of ambivalent and pro-Israeli items were included for balance. The resulting questionnaire was tested on a 
convenience sample of 340 volunteers from King's College London (mostly staff and postgraduate students). Our suspicion that the questionnaire could be potentially distressing for Jewish volunteers was confirmed by a complaint received from a member of staff who stated that the questions made her feel personally uncomfortable. After discussion, the staff member in question explained that her response had been triggered by her recognition of most of the anti-Israeli statements in the questionnaire as ideas that she had had to argue against when confronted by antisemitism.

Weakly correlated items were removed following this initial test, as were two items relating to tactics used by the BDS movement. This was because potential users of the scale who were consulted during the development process expressed concern that including indirect reference to BDS within the scale might make it less useful for future studies investigating the complexity of relationships between BDS and antizionist antisemitism. Antizionist antisemitism could be a motivation underlying BDS, whether conscious, unconscious, or partly conscious; it could be a necessary characteristic of BDS; it could be an empirical outcome of BDS; it could manifest itself in the affective order required by the BDS movement; it might be associated with support for some aspects of BDS but not with support for others. Treating BDS tactics as a component of antizionist antisemitism would make it harder to investigate these possibilities on an empirical level.

One item was re-worded in order to internationalize the scale by removing references to Britain, while another was reworded in order to produce a balance of protrait and contrait (i.e. positively and negatively keyed) items. This process resulted in the six items listed in table 1 , which are intended for presentation in a random order (rather than as here, where protrait items are presented first). Although the items can also be used to assess the prevalence of specific attitudes represented by individual statements, our recommendation is that scores for all six should
TABLE 1 Questionnaire items

\begin{tabular}{ll}
\hline Item & Statement \\
\hline AzAs-1 & $\begin{array}{l}\text { Israel and its supporters are a bad } \\
\text { influence on our democracy }\end{array}$ \\
AzAs-2 & $\begin{array}{l}\text { Israel can get away with anything } \\
\text { because its supporters control the media }\end{array}$ \\
AzAs-3 & $\begin{array}{l}\text { Israel treats the Palestinians like the } \\
\text { Nazis treated the Jews }\end{array}$ \\
AzAs-4 * & $\begin{array}{l}\text { I am comfortable spending time with } \\
\text { people who openly support Israel }\end{array}$ \\
AzAs-5 * & $\begin{array}{l}\text { Israel makes a positive contribution to } \\
\text { the world }\end{array}$ \\
AzAs-6 * & $\begin{array}{l}\text { Israel is right to defend itself against } \\
\text { those who want to destroy it }\end{array}$ \\
\hline
\end{tabular}

* Negatively keyed

also be averaged to provide an overall score for each respondent completing the questionnaire. This is important in distinguishing individuals whose thinking on the issue of Israel is dominated by antisemitism from those who may have agreed with only a single protrait item, or disagreed with a single contrait item, while responding in contrary fashion to all the rest.

\section{FACE VALIDITY OF THE SIX ITEMS}

\section{AzAs-1: Israel and Its Supporters are a Bad Influence on Our Democracy}

Conspiracy fantasy is the bedrock of antisemitism. It portrays Jews as globally powerful and makes Jews a symbol of universal threat. To agree with AzAs-1 in a Western country such as the US or the UK is to agree that Israel could somehow be a threat not only in areas where it is a dominant power, but to "us all."

This question also introduces the notion of "supporters of Israel" - a category referred to in several AzAs items. Obviously, not all supporters of Israel are Jewish and not all Jews are supporters of Israel. But if antisemitic attitudes are imputed onto the category "supporters of Israel," then that is at the very least an indicator of antisemitism, because Israel is the world's 
only Jewish state. Furthermore, a recent survey of British Jews found that ninety percent support Israel's right to exist as a Jewish state, while ninety-three percent consider Israel to be integral to their identity as Jews. ${ }^{16}$ This means that if "supporters of Israel" are seen as a threat, then the majority of Jews will be seen as a threat.

\section{AzAs-2: Israel Can Get Away with Anything Because Its Supporters Control the Media}

Antisemitic conspiracy fantasy often manifests itself in the form of allegations that Jews control and corrupt minds, especially through control of the media industry and the news agenda. Many of the kinds of human rights abuses which anti-Israel campaigners attribute to Israel have their origin in antisemitic superstitions about Jews. Today, supporters of Israel may be treated as a proxy for Jews, and vice versa, in the antisemitic imagination.

To agree with AzAs-2 is therefore to treat Jews as having precisely the same kinds of power and villainy that antisemites have historically ascribed to Jews. This is not refuted by the observation that such power and villainy is at the same stroke ascribed to those non-Jews who join with the majority of Jews in supporting Israel. Indeed, antisemitic conspiracy theory has from the outset implicated non-Jews such as Freemasons and Bolsheviks in the supposed international Jewish conspiracy. ${ }^{17}$

\section{AzAs-3: Israel Treats the Palestinians like the Nazis Treated the Jews}

Holocaust inversion, which constructs Jews as Nazis, is wholly unjustified and clearly antisemitic. ${ }^{18}$ "Nazi," as a term, connotes the absolute evil associated with the ideal and defining type of modern and industrialized genocide. Applying this epithet to Jews, who were the key victims of Nazi genocide, aggravates the connotation. And this applies no less when it is applied to the Jewish state. The International Holocaust Research Association explicitly recognizes " $[\mathrm{d}]$ rawing comparisons of contemporary Israeli policy to that of the Nazis" as one of several examples of potentially antisemitic discourse. ${ }^{19}$ It has further been argued that such comparisons are "almost always" antisemitic, as "it is difficult, if not impossible to imagine a rigorous, rather than a polemical-emotional use of the Nazi analogy." 20

\section{AzAs-4: I Am Comfortable Spending Time with People Who Openly Support Israel}

In the light of the above discussion of the term "supporters of Israel," it is clear that to disagree with AzAs-4 would indicate a disinclination to spend time with the overwhelming majority of Jews. The fact that Jews may be allowed to disavow Israel in the hope of making themselves socially acceptable does not nullify this conclusion. Indeed, requiring Jews to disavow or to keep quiet about an important aspect of their Jewishness before admitting them to non-Jewish society would in itself be a deeply antisemitic practice.

\section{AzAs-5: Israel Makes a Positive Contribution to the World}

This statement is simplified from one of those used in the Jewish Policy Research Institute's study of attitudes to Jews and Israel. ${ }^{21}$ Providing respondents with an opportunity to express a positive view of Israel increases the scale's power to distinguish those whose thinking is influenced by antizionist antisemitism from those whose thinking is not.

To deny that any particular country makes a positive contribution to the world would likely be interpreted as bigoted. It is possible that some individuals may disagree with AzAs- 5 out of ignorance, or because of some other prejudice (for example, a belief that no country but their own could make a positive contribution). However, throughout history, one of the central accusations against the Jews has been that they are unproductive and parasitical. Where 
this accusation is applied to the Jewish state, the implication of antisemitism is clear.

\section{AzAs-6: Israel is Right to Defend Itself against Those Who Want to Destroy It}

Around half of world Jewry is resident in Israel. Denying Israel the right to self-defense would in practice amount to endorsement of a second Holocaust.

\section{PILOT STUDY}

The six-item instrument was piloted on a sample of Mechanical Turk workers in the US, ${ }^{22}$ with the administration of the questionnaire being managed through the TurkPrime platform on 22 July $(N=122){ }^{23}$ See Appendix 1 for demographic characteristics of the sample (collected by TurkPrime using the platform's own demographic categories) and for participants' self-reported political positions (collected through the questionnaire). Political positions were expressed on a five-point left-right scale, where 1 corresponds to "left" and 5 corresponds to "right." As with the development version, the questionnaire was hosted on Google Forms, with informed consent being obtained and with no identifying information being available to the researchers.

Altogether, ninety-seven of the respondents rated all six items, and just three did not rate any items at all (where not rating an item means responding "Don't know," as it was not possible to skip items and still complete the survey). Table 2 gives percentage rates of agreement and disagreement, as well as total numbers of ratings, for each item (the percentage choosing the option "neither agree nor disagree" is not given but can be inferred). Table 3 gives Spearman's coefficient of correlation for each pair of items.

Each respondent was assigned an AzAs score, calculated as the mean of all his or her responses on a five-point scale (where "Strongly disagree" is 1 and "Strongly agree" is 5 for AzAs-1, AzAs-2, and AzAs-3, and the reverse is true for the remaining items). "Don't know" responses were ignored. Table 4 shows the Spearman correlation between each item and the overall AzAs score.

TABLE 2. Agreement and disagreement with items

\begin{tabular}{lccc}
\hline & Total agree $(\%)$ & Total disagree $(\%)$ & $N$ \\
\hline AzAs-1 & 29 & 45 & 114 \\
AzAs-2 & 24 & 51 & 108 \\
AzAs-3 & 34 & 39 & 104 \\
AzAs-4 & 61 & 11 & 114 \\
AzAs-5 & 47 & 19 & 114 \\
AzAs-6 & 72 & 10 & 117 \\
\hline
\end{tabular}

TABLE 3. Item-item correlations

\begin{tabular}{lrrrrrr}
\hline & AzAs-1 & AzAs-2 & AzAs-3 & AzAs-4 & AzAs-5 & AzAs-6 \\
\hline AzAs-1 & 1.00 & 0.36 & 0.61 & -0.57 & -0.58 & -0.54 \\
AzAs-2 & 0.36 & 1.00 & 0.51 & -0.19 & -0.33 & -0.25 \\
AzAs-3 & 0.61 & 0.51 & 1.00 & -0.42 & -0.48 & -0.47 \\
AzAs-4 & -0.57 & -0.19 & -0.42 & 1.00 & 0.55 & 0.66 \\
AzAs-5 & -0.58 & -0.33 & -0.48 & 0.55 & 1.00 & 0.55 \\
AzAs-6 & -0.54 & -0.25 & -0.47 & 0.66 & 0.55 & 1.00
\end{tabular}


As it shows, AzAs-1 was the most strongly correlated (that is, the most predictive of responses to all other items), and AzAs-2 was the least strongly correlated. However, even AzAs-2 was well-correlated with the overall score. Table 5 shows standard measures of internal reliability for the AzAs scale, as well as the mean and standard deviation for AzAs scores for the sample as a whole. Both on Cronbach's alpha and Guttman's lambda- 6 , the scale achieved an acceptable level of internal reliability. ${ }^{24}$ This is evidence, independent of the above arguments for face validity, that the six items may indeed be treated as measuring a single trait.

The mean AzAs score for the sample was below the theoretical midpoint of 3.00, indicating that most respondents reject antisemitic antizionism. However, the theoretical midpoint was well within one standard deviation of the mean, indicating that acceptance of antisemitic antizionism was far from unusual. Figure 1 is a histogram showing the overall distribution of AzAs scores, and figure 2 is a violin plot showing the distribution of AzAs scores for respondents at each level of subjective left-right political identification (horizontal lines represent median

TABLE 4: Item-scale correlations

\begin{tabular}{lc}
\hline & Correlation \\
\hline AzAs-1 & 0.81 \\
AzAs-2 & 0.60 \\
AzAs-3 & 0.78 \\
AzAs-4 & -0.73 \\
AzAs-5 & -0.75 \\
AzAs-6 & -0.75 \\
\hline
\end{tabular}

TABLE 5: Internal reliability, mean, and standard deviation for the AzAs scale as applied to this sample

\begin{tabular}{ll}
\hline & 0.85 \\
$\mathrm{k}_{6}$ & 0.85 \\
$\mathrm{M}$ & 2.58 \\
$\mathrm{SD}$ & 0.80 \\
\hline
\end{tabular}

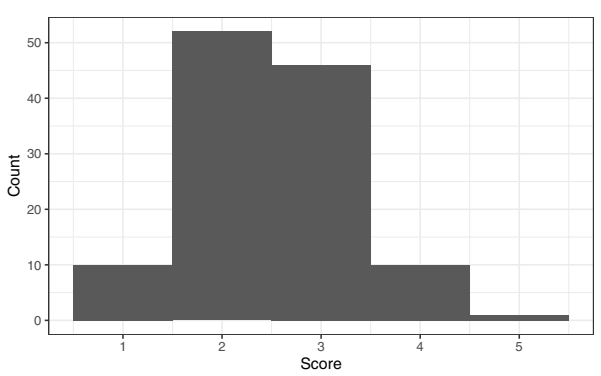

Figure 1. Overall distribution of AzAs scores

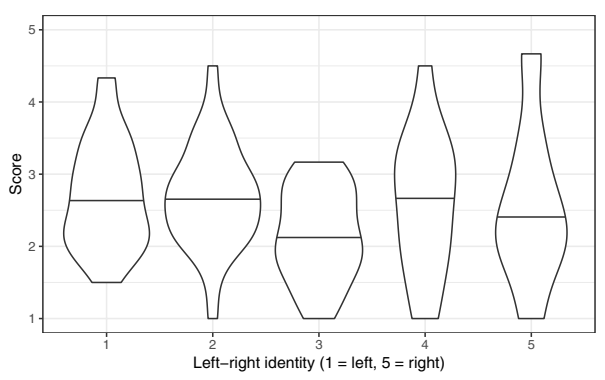

Figure 2. Distribution of AzAs scores for respondents at each level of subjective left-right political identification (horizontal lines represent median scores)

scores). Examination of figure 2 suggests that there is no monotonic component to the relationship between subjective political position and antisemitic antizionism within this sample. In other words, respondents who think of themselves as being on the left appeared neither more nor less likely to agree with antisemitic antizionist statements than respondents who think of themselves as being on the right. However, very few members of this particular sample identified themselves with the political right.

\section{CONCLUSION}

The AzAs scale may be used both to measure the overall appeal of antisemitic attitudes as expressed in relation to Israel and its supporters and in order to judge how widespread certain key attitudes are. Belief in the myth of 
a worldwide Jewish conspiracy remains the most important and dangerous of antisemitic attitudes, so it is important that we are able to detect such ideation even when couched in such a way as to avoid explicit reference to Jews qua Jews. As such, the AzAs scale will be a useful research tool in studying contemporary antisemitism and its relation to other social, political, and psychological phenomena.

\section{ACKNOWLEDGEMENTS}

We are grateful for the participation of the volunteers at King's College London who helped to develop the scale, to the experts and activists who discussed the scale with us while it was in development, and to the Mechanical Turk workers who completed the questionnaire used in order to pilot the scale for this study.

\section{TECHNICAL NOTE}

All calculations and visualizations were carried out using $\mathrm{R}$ version 3.5.1, with substantial use of the packages psych and ggplot $2 .{ }^{25}$

\section{APPENDIX}

TABLE 6: Demographic characteristics of respondents, where available (collected by TurkPrime)

\begin{tabular}{lcc}
\hline Demographic & $\%$ & N \\
\hline Gender: Female & 43 & 50 \\
Gender: Male & 57 & 67 \\
Birthdate: 1979 or earlier & 23 & 26 \\
Birthdate: 1980 or later & 77 & 87 \\
'Race': White/Caucasian & 79 & 90 \\
'Race': other & 21 & 24 \\
\hline
\end{tabular}

TABLE 7: Left-right identification of respondents

\begin{tabular}{lll}
\hline & $\%$ & $N$ \\
\hline 1 Left & 34 & 41 \\
2 & 27 & 33 \\
3 & 20 & 24 \\
4 & 11 & 13 \\
5 Right & 7 & 8 \\
Don't know & 2 & 3 \\
\hline
\end{tabular}

\section{REFERENCES}

1 A version of this paper was presented at the 14th Conference of the European Sociological Association (Manchester, 2019. The authors are grateful for feedback received on that occasion.

2 *Address for correspondence: daniel.allington@kcl.ac.uk

3 W. Frindte, S. Wettig, and D. Wammetsberger, "Old and New Antisemitic Attitudes in the Context of Authoritarianism and Social Dominance Orientation: Two Studies in Germany," Peace and Conflict: Journal of Peace Psychology 11, no. 3 (2005): 239-266; E. H. Kaplan and C. A. Small, "Anti-Israel Sentiment Predicts Antisemitism in Europe, Peace and Conflict: Journal of Peace Psychology 50, no. 4 (2006): 548-561; F. Cohen, L. Jussim, K. D. Harber, and G. Bhasin, "Modern Antisemitism and Anti-Israeli Attitudes," Peace and Conflict: Journal of Peace Psychology 97, no. 2 (2009): 390-306; L. Weinstein and C. Jackson, "College Student Antisemitism and Anti-Israeli Sentiment, College Studies Journal 44, no. 2 (2010): 265-267; V. Swami, "Social Psychological Origins of Conspiracy Theories: The Case of the Jewish Conspiracy Theory in Malaysia," Frontiers in Psychology 3, no. 228 (2012): 1-19; R. Jaspal, "Antisemitism and Anti-Zionism in Iran: The Effects of Identity, Threat, and Political Threat," Contemporary Jewry 35, no. 3 (2015); L. D. Staetsky, Antisemitism in Contemporary Great Britain: A Study of Attitudes Towards Jews and Israel, (London: Institute for Jewish Policy Research, 2017) https://cst.org.uk/public/data/file/7/4/JPR.2017. Antisemitism\%20in\%20contemporary\%20Great\%20Britain.pdf.

4 R. Wistrich, The Politics of Ressentiment: Israel, Jews and the German Media (Jerusalem: Vidal Sassoon International Center for the Study of Antisemitism, 2004); P.-A. Taguieff, Rising from the Muck: The New AntiSemitism in Europe (Chicago: Ivan R. Dee, 2004); D. Hirsh, Anti-Zionism and Antisemitism: Cosmopolitan 
Reflections (New Haven: Yale Initiative for the Interdisciplinary Study of Antisemitism, 2007); A. Julius, Trials of the Diaspora: A History of Anti-Semitism in England (Oxford: Oxford University Press, 2010); R. Jaspal, Antisemitism and Anti-Zionism: Representation, Cognition, and Everyday Talk (Abingdon: Routledge, 2014), 211-235; D. Hirsh, Contemporary Left Antisemitism (Abingdon: Routledge, 2017); D. Rich, The Left's Jewish Problem: Jeremy Corbyn, Israel, and Anti-Semitism, 2nd ed. (London: Biteback Publishing, 2016). David M., Seymour, "Antisemitism and Antizionism: Ideologies of the Jewish Question," Journal of Contemporary Antisemitism 2, no. 2 (2019).

5 J. K. Nelson, "Denial of Racism and Its Implications for Local Action," Discourse and Society 24, no. 1 (2013): 89.

6 Staetsky, Antisemitism, 22, 29.

7 See, Catherine D. Chatterley, "Leaving the Post-Holocaust Period: The Effects of Anti-Israel Attitudes on Perceptions of the Holocaust," in Anti-Zionism and Antisemitism: The Dynamics of Delegitimization, ed. Alvin H. Rosenfeld (Indiana: Indiana University Press, 2019), 158-174.

8 Staetsky, Antisemitism, 36.

9 Assaf Orion and Shahar Eilam, "Highlights of the Strategic Assessment," in The Delegitimization and BDS Threat to Israel and Diaspora Jewry, ed. Assaf Orion and Shahar Eilam (Tel Aviv: Institute for National Security Studies, 2019), 28-29.

10 See Hirsh, Contemporary Left Antisemitism, chapter 4.

11 Orion and Shahar, "Highlights of the Strategic Assessment," 26.

12 Benjamin Weinthal, "German Court Calls Synagogue Torching a 'Justified Action to Criticize Israel,', Jerusalem Post, January 15, 2017.

13 Thorsten Fuchshuber, "From Wilhelm Marr to Mavi Marmara: Antisemitism and Anti-Zionism as Forms of AntiJewish Action," in Rosenfeld, Anti-Zionism and Antisemitism, 30-52.

14 Fuchshuber, "From Wilhelm Marr to Mavi Marmara, 35.

15 Seymour.

16 Stephen Miller, Margaret Harris, and Colin Shindler, The Attitudes of British Jews Towards Israel (London: City University, 2015).

17 See N. Cohn, Warrant for Genocide: The Myth of the Jewish World-Conspiracy and the Protocols of the Elders of Zion (London: Eyre \& Spottiswoode, 1967).

18 L. Klaff, "Holocaust Inversion and Contemporary Antisemitism," fathom (Winter 2014), http://fathomjournal.org/ holocaust-inversion-and-contemporary-antisemitism/.

19 IHRA, "Working Definition of Antisemitism," https://www.holocaustremembrance.com/working-definitionantisemitism.

20 James Wald, "The New Replacement Theory: Anti-Zionism, Antisemitism, and the Denial of History," in Rosenfeld, Anti-Zionism and Antisemitism, 10.

21 Staetsky, Antisemitism, 29.

22 Mechanical Turk is a crowdsourcing marketplace owned by Amazon.

23 For explanation of TurkPrime, see Leib Litman, Jonathan Robinson, and Tzvi Abberbock, "TurkPrime.com: a Versatile Crowdsourcing Data Acquisition Platform for the Behavioral Sciences," Behavior Research Methods 49, no. 2: 433442.

24 See the effectively identical Cronbach's alpha for the much longer "anti-Israel" scale used in the Jewish Policy Research study (Staetsky, Antisemitism, 33).

25 William Revelle, psych: Procedures for Psychological, Psychometric, and Personality Research. Version 1.8.10, https://CRAN.R-project.org/package=psych; Hadley Wickham. ggplot2: Elegant Graphics for Data Analysis (New York: Springer-Verlag, 2009). 
